\title{
How can we Implement the ALA Standards for College Libraries?
}

By FELIX E. HIRSCH

T HE ACRL Committee on Standards has always felt that the responsibility for devising standards for college libraries is ours and that of the officers of the association to which we belong. But we made every possible effort in our preparation of the AI.A Standards for College Libraries to get a consensus of college librarians from all over the country and to consult leading educators, be they college presidents or officers of accrediting associations, in order to secure their good advice and to see more clearly with their help the functions which the college library should fulfill in the framework of higher learning in America. Many of their suggestions were incorporated in the new Standards and all their criticisms were weighed carefully.

As we prepared the three drafts of the standards for college libraries we had several aims clearly in mind. We wanted to design a document that would provide a blueprint for the 1960's. We knew full well that we could not hope to produce a tool that would be good for much more than a decade, since conditions are changing so rapidly. Teaching methods have been modified in the last ten years, with a growing emphasis on independent study which in turn has important consequences for the use of the library. The rapid increase in student population is beginning to make itself felt and may bring about revolutionary changes. Book production also has entered a new era. May I mention here that ten years ago, at the ALA conference in Cleveland, I appealed to the publishers to bring out good books for a dollar since there was "an enormous potential market for books of this kind in the U.S.A.," especially
Mr. Hirsch is Librarian and Professor of History, Trenton State College, Trenton, N. J., and Chairman of the ACRL Committee on Standards. This paper was presented at a meeting of the ACRL College Libraries Section, Montreal, June 21, 1960.

among college students, ${ }^{1}$ only to be told point-blank by the spokesman of the American Book Publishers Council with whom I shared the platform, that my idea was fine for England and Germany, but not practicable in this country. Well, in 1960, the situation certainly has changed; libraries see in the college bookstore with its tempting array of quality paperbacks an important ally rather than a potential competitor. Who knows what the publishers may be up to in 1970? Another unforeseeable factor is the progress of technical inventions, such as closed circuit television, which may have an impact on the use of books and other library materials. The last unpredictable factor is the value of our currency. We omitted any dollar sign from our document since the purchasing power of the U. S. currency is so uncertain, and especially since book prices have been rising constantly in the 1950's. Surely nobody would be helped in the long run by some flat statement that a library should spend annually $\$ 10$ or $\$ 15$ per student for books, even though some administrators seem to like such formulas.

While we omitted the dollar signs, we felt we had to give, at least, a few quantitative measurements, although the emphasis in the Standards is clearly on quality. We recognized that there is one

1 Felix E. Hirsch, "The Librarian Looks at the Publisher," CRL, XII (1951), 321-327. 
figure whose importance is shown by long experience in good college libraries and could, therefore, serve as a kind of foundation stone-the percentage the library receives of the total general and educational budget of an institution. There is nothing magic about the figure of 5 per cent which we recommend, but it so happens that practically all outstanding college libraries, big or small, state or private, nondenominational or sectarian, spend about that much or more of the general and educational budget of their institution, and that the national median is usually not far below 5 per cent. On the other hand it can be stated on the basis of many college library evaluations that libraries having poor collections and giving poor service are likely to receive much less than 5 per cent of the general and educational budget. The other figures which we deemed essential if the standards were to fulfill their proper function, are the minimum size of the staff, the size of the collection, and the seating capacity. In all these cases, our conclusions were based on the available statistical evidence, on the judgment of leading authorities, and on our own observations. It so happened that most members of the committee had been connected with two or three types of college libraries in various parts of the country and therefore were able to take a broad view. We knew that college libraries have their individual character and are wrestling with their specific institutional problems. What was needed, therefore, were flexible standards based on firm principles rather than cumbersome mathematical formulas which could never do full justice to a particular situation.

Throughout the standards we set our sights high. The status quo is just not good enough to serve as a standard for tomorrow! We believe that the 1960's will be an auspicious time to strike out for better and richer college libraries, because the general public has become concerned about the need for strengthening our whole educational system and with it, of course, the college libraries. The bigger the enrollment and the more complex the curriculum, the more a college must be able to rely on the educative influence of the college library. We tried to make the Standards readable and to keep them brief, because we hoped that in this way they might reach a wider audience on and off the campus and serve-to use an observation made by my late friend and teacher Dr. Charles Harvey Brown of Iowa State in his last letter to me-as a kind of short handbook of college library administration.

As we ponder the implementation of the Standards, let me emphasize that the document intentionally avoids any reference to regional differences. It was our hope that by the end of this decade the still existing regional differences among college libraries may have worn off. It is our conviction that the "double standard" which used to be observed between the libraries of liberal arts colleges and those of the institutions devoted to teacher education or engineering will also gradually disappear. We firmly believe that there will remain always a difference in emphasis between them, but that they should strive equally for excellence.

The implementation of the Standards must begin in our daily work. Without much ado, we should endeavor to bring to reality the concept of the librarian as an educator, a concept which underlies the whole document. We have to prove again and again by all our attitudes that we are not just custodians of books, as some faculty members still suspect, but that we are equal partners of the teaching faculty. Still there are many colleges across the country in which the library staff, with the possible exception of the head librarian, is given a treatment not much better than that given clerical personnel. That is why it is so important that we implement the demand of the Standards that every professional librarian be given faculty status. 
This presupposes that the library profession attracts more and more suitable candidates, men and women who show the promise to become as excellent as the most inspiring college professors are, and that our own staff members are selected with utmost care. They should be so broadly educated and widely interested that faculty members will welcome them with open arms. A professional librarian should hold a degree from a recognized library school (by the way, the presidents of a few of our leading colleges doubted the wisdom of this prescription), but the Standards indicate the desirability of further graduate studies, possibly in some subject area. It stands to reason that the reference librarian who holds a master's degree in English literature will have an easier access to the English department and is likely to understand more about the problems of scholarly research in general than the reference librarian who has confined himself to library school training. For such highly competent people we should try to devise an incentive by providing better working conditions and especially by easing the road to promotion. Sometimes we might also secure for them opportunities to teach a course in an academic subject. This is, if I may speak from my own long teaching experience and that of some staff members at Trenton State, a very effective method of bridging the gap between the library and the classroom and of establishing better channels of communication with the student body which is and always will be the most important segment of the college community for the librarian. College students, I might add here, size us up very fast; they sense right away on whose help they can rely and they tiptoe around those who would only refer them to the Reader's Guide. May I also underscore the suggestion of the Standards to have a student committee on the library; it may be a great help to the librarian, provided he defines its functions properly.

If the high caliber of the staff is the first requirement for a good college library, the second is the rich and up-todate collection of books, periodicals, and other materials. The Standards offer many suggestions for its development. While faculty advice is the indispensable foundation, let us do our share to strengthen the collection by constantly checking recent bibliographies, scholarly book reviews, etc., in many fields to supplement the suggestions coming from instructors. It is especially important that by our own book selection we help to provide a situation in which the student will have access to all major currents of thought, will have an opportunity to familiarize himself also with the nonWestern civilizations, and, above, all will feel encouraged to develop the life-time habit of good reading, in spite of the temptations of television and rock-androll. And let us make sure that the provision of the Standards which denounces any form of censorship in the college library, is carried out without fail.

College libraries cannot exist on a lonely island. We should cooperate more closely and more effectively with our neighbors. The Standards refer to the Hampshire Inter-Library Center; we might also have pointed to the fruitful collaboration of the Quaker colleges in the Philadelphia area. While cooperation is a virtue and will make the library dollar go much farther, no college library should rely on its neighbors for essential services. We must stand on our own feet; we must take care of our own readers. The head of an institution around Washington who told me recently in all seriousness that he needs only a small library collection because his faculty and students could use the Library of Congress as their "community resource," is not such a rare bird as you might think; he has plenty of company. The Standards are quite clear about our obligation in this respect. We must try to carry it out not only in our undergraduate division, but with the same firmness regarding 
those Master's programs which have mushroomed in many colleges lately. Even if no person in authority on his campus wants to side with him, the librarian must fight for proper additional allocations so that graduate students may enjoy the research facilities to which they are entitled and without which the whole program would be an abysmal failure, if not a fake. The Standards are precise on this issue, and the admirable recent document of the Middle States Association on graduate study also leaves no doubts in this respect.

These are a few observations about important points in the Standards. They can be a strong weapon in your hands, if you use them judiciously. They may not help you on every minor issue that arises on your campus between some other departments and the library. But they may be your best aid in interpreting the functions of the library to your authorities. They certainly can be a factor in creating the right atmosphere for the library on campus, if you put copies into the proper hands. Let me give a few examples: ACRL headquarters sent a complimentary copy of the standards to every college president in the country. Many wrote very favorable letters back, and some went into action. One morning last March the phone in my office rang. At the other end, a few hundred miles away, was the president of a college in the Middle States area. He had read the Standards, had discussed them with his libraian, and had been worried about how his institution would rate on them. He proposed that two librarians from his state and I, serving as chairman and coming from the outside, should undertake a thorough survey of his library to propose a plan of action. The three of us went there in April and presented to the president in May a long, analytical report with precise and rather radical proposals to be carried out over a four-year period. The latest letter from the librarian indicates that some extra money for books has already begun to come in and that the budget bureau has promised a much larger allocations for 1961-1962. He added that the president will distribute the whole text of the survey to his superiors as well as to all faculty members, few of whom can be pleased with some of our findings. Another example: the librarians of some New Jersey state colleges have used the Standards to good advantage to point up the long-range needs of their individual libraries; the results have been encouraging. The state authorities have been persuaded gradually of the wisdom of much larger appropriations than could have been imagined five years ago. The Standards have also helped me in negotiating with state authorities about the remodeling of our library.

That the Middle States Association also played an important role in this process of conversion, if I may call it so, is gratefully acknowledged. Actually, there can be nothing more fruitful than the cooperation between accrediting agency and librarians using the new Standards. To give also an example from another part of the country, I was told by a prominent librarian from North Carolina not long ago that evaluation teams for the Southern Association take our Standards along on their journeys and find them helpful for their purposes. It is up to those of us who serve on such evaluations to do our utmost to impress the meaning of the Standards on those whom we visit and to include the basic tenets in our recommendations, wherever needed.

When the Standards were published in CRL last year, five thousand reprints were made for distribution free or, in multiple copies, at a nominal fee. They were exhausted in less than three months, because quite a few librarians secured enough copies to circulate them to their faculty committees and to their authorities. Since then, a second printing has become available. Let me reiterate here what I said before: some copies, placed 
in strategic spots on your campus, may help you in explaining and perhaps even solving your problems. Possibly you may be able to suggest a discussion of the Standards as a topic for a faculty meeting. This could become the starting point for a self-survey of your collections, jointly sponsored by library staff and teaching faculty. Or maybe you would wish to do what the library staff at Trenton State did just a few months ago. We undertook an informal job analysis for all staff members in the light of what the Standards have to say. The result indicated clearly the need for two new professional positions, and we applied for them in time for the next budget (for $1961 / 62$ ) to be set up.

These are a few practical hints about the implementation of the Standards. But high above practical considerations stand the long-range aims of the Standards. They are to help our profession realize the vision of the college library as the intellectual powerhouse of the academic community. The task before us has rarely been expressed more beautifully than by Woodrow Wilson, speak- ing on the Swarthmore Founders Day in October 1913. "I cannot admit," he said, "that a man establishes his right to call himself a college graduate by showing me his diploma. The only way he can prove it is by showing that his eyes are lifted to some horizon which other men less instructed than he have not been privileged to see. Unless he carries freight of the spirit he has not been bred where spirits are bred. . . . You are here [he said to the students] in order to enable the world to live more amply, with greater vision, with a finer spirit of hope and achievement. You are here to enrich the world, and you impoverish yourself if you forget the errand." The libraries of distinguished institutions like Swarthmore or Wilson's alma mater, Princeton, have long furnished their students with the kind of intellectual nourishment on which his idea of the college graduate must rest. It is our hope that the Standards, imaginatively and courageously used, may help to make Wilson's dream come true also in many of the smaller and less renowned colleges of America and their struggling libraries.

\section{Library Statistics Available}

Management data on 1,401 academic libraries are given in part 1 of Library Statistics of Colleges and Universities, 1959-60, compiled by John Carson Rather and Doris C. Holladay of the Library Services Branch, U. S. Office of Education. The publication, first of two based on a national survey, also includes salaries of specified full-time library positions in 866 institutions, as of September 1, 1960. An analysis of the data will appear in the late spring.

Copies of the institutional listing have been mailed to academic librarians, state departments of education, large public libraries, and many other agencies concerned with this field. Single copies are available free on request from the Publications Inquiry Unit, U. S. Office of Education, Washington 25, D. C. Multiple copies should be purchased at fifty cents each from the Superintendent of Documents, Washington 25, D. C. 